\title{
Effects of phenylmethylsulphonylfluoride on activities of cholesteryl ester synthesis and hydrolysis in testes of rats, and on serum testosterone and LH levels
}

\author{
T. Takatori and A. Yamaoka \\ Department of Legal Medicine, Hokkaido University School of Medicine, Sapporo 060, Japan
}

\begin{abstract}
Summary. PMSF was injected subcutaneously to male rats once a day for 10 days at a dose of $10 \mathrm{mg} /$ day. There was an increase in the concentrations of free and esterified cholesterol in the testes, a decrease in activities of cholesteryl ester synthesis and hydrolysis but no change in activity of cholesterol side-chain cleavage enzyme. Serum testosterone and LH levels were significantly decreased. The only effect of PMSF on the lipids of the testes was a marked elevation of docosapentaenoic $(22: 5)$ acid in the cholesteryl esters.
\end{abstract}

\section{Introduction}

Sulphonyl fluorides have been well recognized as inhibitors of esterases (Kitz \& Wilson, 1962; Pavlic, 1970; Alid \& Orrego, 1972). Bartke, Musto, Caldwell \& Behrman (1973) reported that administration of phenylmethylsulphonylfluoride (PMSF) to male mice causes an accumulation of testicular cholesteryl esters and a decrease in plasma testosterone level. Although cholesteryl esters in testes are important as precursors of androgenic steroids (Bartke, 1971a; Hafiez \& Bartke, 1972; Hafiez, Lloyd \& Bartke, 1972a) and are rich in essential fatty acids, particularly docosapentaenoic acid which is believed to be important in spermatogenesis (Davis, Bridges \& Coniglio, 1966; Goswami \& Williams, 1967), the physiological role of these fatty acids in testicular function has not been elucidated.

In a previous study (Takatori, Phillips \& Privett, 1976) we investigated the enzymic properties of cholesteryl ester synthesis and hydrolysis in rat testes. The present study was conducted to determine the effects of PMSF on cholesteryl ester synthesis and hydrolysis in rat testes and the activity of cholesterol side-chain cleavage enzyme, together with changes in serum testosterone and $\mathrm{LH}$ levels.

\section{Materials and Methods}

Experimental animals. Male rats of the Sprague-Dawley strain, weighing 200-250 g, were used. A fresh solution of PMSF, dissolved in sesame oil, was made up each day. PMSF was injected subcutaneously in a volume of $0.2 \mathrm{ml}$ once a day for 10 days at a dose of $10 \mathrm{mg}$ per injection; sesame oil only was injected into control animals. Blood samples were collected into glass microcapillary tubes $(100 \mu \mathrm{l})$ from the orbital venous plexus of rats, lightly anaesthetized with ether, $12 \mathrm{~h}$ after the last injection. After clotting at $4^{\circ} \mathrm{C}$. serum was obtained by centrifugation and stored at $-20^{\circ} \mathrm{C}$ until used. The rats were weighed before the first and after the last injection.

Enzyme preparations. Immediately after blood sampling, the animals were killed by exsanguination and the testes removed and weighed. Half of each testis was kept for lipid analysis at $-20^{\circ} \mathrm{C}$ until assayed. After removal of capsule and visible blood vessels from the 
residual testicular tissue, the tissue was minced and homogenized as previously described (Takatori et al., 1976). Cell debris and nuclei were separated from the homogenates by centrifugation at $750 \mathrm{~g}$ for $15 \mathrm{~min}$; the supernatant was then a source of cholesterol esterifying and cholesteryl ester hydrolysing enzymes. An aliquot of the supernatant was centrifuged at $6500 \mathrm{~g}$ for $25 \mathrm{~min}$. The sediment was then suspended in four times its volume of $0.25 \mathrm{M}$ buffered sucrose solution ( 3 parts sucrose and 1 part $0.066 \mathrm{M}$-sodium phosphate buffer, pH 7.2) and centrifuged at $20000 \mathrm{~g}$ for $15 \mathrm{~min}$ as described by Menon, Dorfman \& Forchielli (1967). The sediment thus obtained was resuspended in the same solution and the washing repeated three times to obtain a mitochondrial fraction which was used as the source of cholesterol side-chain cleavage enzyme. All procedures were carried out at $4^{\circ} \mathrm{C}$ and the protein content of the enzyme preparations was determined by the method of Lowry, Rosebrough, Farr \& Randall (1951).

Substrates and other chemicals. The radioactive substances, $\left[4-{ }^{14} \mathrm{C}\right]$ cholesterol (sp. act. $55 \cdot 2$ $\mathrm{mCi} / \mathrm{mmol}$ ), $\left[4{ }^{14} \mathrm{C}\right]$ cholesteryl oleate (sp. act. $55 \cdot 2 \mathrm{mCi} / \mathrm{mmol}$ ), $\left[26^{-14} \mathrm{C}\right]$ cholesterol (sp. act. $56.9 \mathrm{mCi} / \mathrm{mmol}$ ), $\left[1 \beta, 2 \beta-{ }^{3} \mathrm{H}\right]$ testosterone (sp. act. $59 \mathrm{Ci} / \mathrm{mmol}$ ) and $\mathrm{Na}^{125} \mathrm{I}$ (carrier free), were purchased from New England Nuclear Corporation, Boston, Massachusetts. Impurities in the labelled cholesterol and cholesteryl oleate were separated from these preparations by thin-layer chromatography using plates coated with silica gel $\mathrm{H}$ and a solvent system of petroleum ether : diethyl ether :acetic acid ( $85: 15: 1$, by vol.). PMSF was obtained from Sigma Chemical Company. Antibody to testosterone-11 $\alpha$-hemisuccinate conjugated to bovine serum albumin (BSA) was supplied from Teikoku Hormone Company, Japan. Scintillation chemicals and all other reagents were purchased from Wako Pure Chemical Industry, Japan.

Cholesterol esterifying and cholesteryl ester hydrolysing activities. The incubation systems and analytical procedures were carried out as previously described (Takatori et al., 1976); the optical conditions for esterification and hydrolysis were as defined, except that $\left[4-{ }^{14} \mathrm{C}\right]$ cholesteryl oleate was used as a substrate for determination of the hydrolysing activity. Concentrations of endogenous cholesterol and cholesteryl esters in the homogenates were determined in separate experiments by an enzymic method with a commercial kit containing cholesterol ester peroxidase and/or cholesterol oxidase coupled to peroxidase, phenol and 4-aminoantipyrine (Kyowa Fermentation Company, Japan), using the method described by Allain, Poon, Chan, Richmond \& Fu (1974). All incubations were carried out in duplicate, and the enzyme activities were expressed as nmol cholesterol esterified or cholesteryl ester hydrolysed per $\mathrm{h}$ per mg protein.

Cholesterol side-chain cleavage enzyme activity. The activity of cholesterol side-chain cleavage enzyme was assayed exactly as described by Menon et al. (1967), using $\left[26-{ }^{14} \mathrm{C}\right] \mathrm{chol}$ esterol as a substrate without addition of exogenous cholesterol. The incubation medium consisted of $\left[26-{ }^{14} \mathrm{C}\right]$ cholesterol (250 000 c.p.m.) in $20 \mu \mathrm{l}$ propylene glycol, $0.1 \mathrm{ml}$ phosphate buffer $(0.066$ $\mathrm{M}, \mathrm{pH} 7.2$ ) containing $20 \mu \mathrm{mol} \mathrm{MgCl}_{2}, 6 \mathrm{mg}$ DL-isocitric acid, trisodium salt, and $1 \mathrm{mg} \mathrm{\textrm {NDP } ^ { + }}$ and enzyme preparation suspended in $0.8 \mathrm{ml}$ buffered sucrose. The final volume was adjusted to $2 \mathrm{ml}$ with $0.066 \mathrm{M}$ phosphate buffer ( $\mathrm{pH} \mathrm{7.2).} \mathrm{Incubations} \mathrm{were} \mathrm{carried} \mathrm{out} \mathrm{in} \mathrm{air} \mathrm{at} 37^{\circ} \mathrm{C}$ with constant shaking for $90 \mathrm{~min}$. The reaction was stopped by the addition of $0.5 \mathrm{ml} 1.5 \mathrm{M} \mathrm{H}_{2} \mathrm{SO}_{4}$. The converted $\left[{ }^{14} \mathrm{C}\right]$ isocaproic acid was quantitatively collected by a steam distillation with a micro-Kjeldahl apparatus, and the ${ }^{14} \mathrm{C}$ activity was measured with a dioxane scintillant. Because of the efficiency of this method, $\left[4-{ }^{14} \mathrm{C}\right]$ cholesterol was added to the incubation medium in separate experiments. The cholesterol contamination of the acid fraction was less than 30 c.p.m. ${ }^{14} \mathrm{C}$. All incubations were carried out in duplicate, and the enzyme activity was expressed as a percentage of the substrate converted to $\left[{ }^{14} \mathrm{C}\right]$ isocaproic acid per $\mathrm{h}$ per $10 \mathrm{mg}$ protein.

Hormone concentrations. The concentration of serum testosterone was determined by the radioimmunoassay described by Hillier, Brownsey \& Cameron (1973). Antibody to testosterone-11 $\alpha$-hemisuccinate-BSA was used without chromatography because the cross-reaction to dihydrotestosterone was $<10 \%$. The sensitivity of the assay was approximately $15 \mathrm{pg}$ testoster- 
one. In all experiments a $200 \mu \mathrm{l}$ aliquot of the sample was measured in duplicate. The intra-assay coefficient of variation was $3 \cdot 6 \%$.

Serum LH was measured by the radioimmunoassay described by Daane \& Parlow (1971), using reagents supplied by the National Institute of Arthritis and Metabolic Diseases (NIAMD). The results are expressed in terms of the reference preparation (NIAMD-RAT-LH-RP1). All $\mathrm{LH}$ values were measured in duplicate in a $200 \mu \mathrm{l}$ aliquot of the sample. The sensitivity of the assay was $2.9 \mathrm{pg} / \mathrm{ml}$ and the intra-assay coefficient of variation was $4.2 \%$.

Lipid analysis. The lipid was extracted from testicular tissue with chloroform : methanol $(2: 1$ $\mathrm{v} / \mathrm{v}$ ). The content of cholesterol and cholesteryl esters was determined by an enzymic method with the commercial kit as described above. The lipid classes were isolated by thin-layer chromatography with the solvent system of petroleum ether: diethyl ether :acetic acid $(85: 15: 1$, by vol.). Fatty acid composition was determined by gas-liquid chromatography of methyl esters prepared by esterification of the total lipid or lipid classes, and by using $5 \% \mathrm{HCl}$ in methanol as a catalyst (Stoffel, Chu \& Ahrens, 1959). The chromatography was carried out with a ShimadzuGC-6A apparatus equipped with a hydrogen flame detector with a $0.3 \times 200 \mathrm{~cm}$ column packed with 3\% EGSS-X on Chromosorb W (80-100 mesh) at $190^{\circ} \mathrm{C}$ as previously described (Takatori \& Yamaoka, 1977). The percentage distribution of the fatty acids was determined from the proportions of the peak areas. Identification of the peaks was made on the basis of the retention times of known methyl esters. Trace components $(<0.2 \%)$ or unknown peaks were ignored.

Statistical significance was determined by using the Student's $t$ test.

\section{Results}

Table 1 shows that PMSF had no influence on body weight or testicular weight, but resulted in a significant increase in the concentration of free and esterified cholesterol in the testes. Cholesterol esterification and cholesteryl ester hydrolysis were significantly suppressed by PMSF, being 63 and $43 \%$ respectively of the control values (Table 2 ). The hydrolysing activity was therefore more susceptible to PMSF. The activity of cholesterol side-chain cleavage enzyme was unchanged. The concentrations of serum testosterone and LH were significantly decreased by administration of PMSF (Table 2). The fatty acid compositions of the individual lipid classes showed that marked differences existed in the cholesteryl esters of the testicular lipids of the animals treated with PMSF (Table 3). The most striking of these was the increase in docosapentaenoic $(22: 5)$ acid $(11.5$ to $20.3 \%)$ in the cholesteryl ester fraction.

Table 1. Effects of phenylmethylsulphonylfluoride (PMSF) on the weight of body and testes, and on the concentrations of free and esterified cholesterol in the testes of rats

\begin{tabular}{lcc}
\hline & Control & PMSF \\
\hline No. of rats & 5 & 7 \\
Initial body weight (g) & $200 \pm 4.47$ & $201 \pm 2.27$ \\
Final body weight (g) & $234 \pm 8.94$ & $214 \pm 4.91$ \\
Wt of paired testes (g) & $2.6 \pm 0.04$ & $2.7 \pm 0.04$ \\
Free cholesterol (mg/g wet wt) & $1.54 \pm 0.06$ & $1.77 \pm 0.03^{*}$ \\
Esterified cholesterol (mg/g wet wt) & $0.08 \pm 0.013$ & $0.16 \pm 0.015 \dagger$ \\
\hline
\end{tabular}

Values are mean \pm s.e.m.

* Significantly different from control value, $P<0.01$.

$\dagger$ Significantly different from control value, $P<0.005$. 
Table 2. Effects of phenylmethylsulphonylfuoride (PMSF) on activities of cholesterol esterification, cholesteryl ester hydrolysis and cholesterol side-chain cleavage enzyme in the testes of rats, and on testosterone and LH levels in the serum

\begin{tabular}{|c|c|c|c|}
\hline & Control & PMSF & $P$ \\
\hline No. of rats & 5 & 7 & \\
\hline $\begin{array}{l}\text { Esterifying activity } \\
\text { (nmol cholesterol esterified } / \mathrm{h} / \mathrm{mg} \text { protein) }\end{array}$ & $4 \cdot 48 \pm 0 \cdot 15$ & $2.82 \pm 0.09$ & $<0.001$ \\
\hline $\begin{array}{l}\text { Hydrolysing activity } \\
\text { (nmol cholesteryl ester hydrolysed } / \mathrm{h} / \mathrm{mg} \text { protein) }\end{array}$ & $8 \cdot 28 \pm 0 \cdot 30$ & $3 \cdot 55 \pm 0 \cdot 12$ & $<0.001$ \\
\hline $\begin{array}{l}\text { Cleavage enzyme activity } \\
\text { (\% substrate converted to }\left[{ }^{14} \mathrm{C}\right] \text { isocaproic acid/h/10 mg } \\
\text { protein) }\end{array}$ & $2.37 \pm 0.035$ & $2 \cdot 30 \pm 0.24$ & \\
\hline Testosterone $(\mathrm{ng} / \mathrm{ml}$ serum) & $1.07 \pm 0.058$ & $0.76 \pm 0.057$ & $<0.005$ \\
\hline LH (ng/ml serum) & $18 \cdot 4 \pm 2 \cdot 15$ & $10 \cdot 2 \pm 1 \cdot 55$ & $<0.025$ \\
\hline
\end{tabular}

Values are mean \pm s.e.m.

Table 3. Fatty acid composition of testicular tissue lipid of rats after administration of phenylmethylsulphonylfluoride (PMSF)

\begin{tabular}{|c|c|c|c|c|c|c|c|c|c|c|}
\hline \multirow[b]{2}{*}{ Treatment } & \multirow{2}{*}{$\begin{array}{l}\text { No. of } \\
\text { rats }\end{array}$} & \multicolumn{9}{|c|}{ Fatty acid content ( $\%$ by weight) } \\
\hline & & $C_{16: 0}$ & $\mathrm{C}_{16: 1}$ & $\mathrm{C}_{18: 0}$ & $\mathrm{C}_{18: 1}$ & $C_{18: 2}$ & $\mathrm{C}_{20: 3}$ & $\mathrm{C}_{20: 4}$ & $\mathrm{C}_{22: 4}$ & $\mathrm{C}_{22: 5}$ \\
\hline \multicolumn{11}{|c|}{ Total lipid } \\
\hline Control & 5 & $\begin{array}{c}35.0 \\
\pm 0.81\end{array}$ & $\begin{array}{c}1.4 \\
\pm 0.045\end{array}$ & $\begin{array}{c}7.9 \\
+0.45\end{array}$ & $\begin{array}{c}12.1 \\
\pm 0.31\end{array}$ & $\begin{aligned} & 6.2 \\
+ & 0.63\end{aligned}$ & $\begin{array}{c}1.0 \\
+0.13\end{array}$ & $\begin{array}{c}15.6 \\
+0.36\end{array}$ & $\begin{array}{c}2.4 \\
+0.27\end{array}$ & $\begin{array}{r}18.5 \\
+0.58\end{array}$ \\
\hline PMSF & 7 & $\begin{array}{c}34.6 \\
\pm 0.64\end{array}$ & $\begin{array}{l}1.9 \\
+0.19\end{array}$ & $\begin{aligned} & 8.7 \\
+ & 0.26\end{aligned}$ & $\begin{array}{c}14.1 \\
\pm 0.23\end{array}$ & $\begin{aligned} & 5.6 \\
+ & 0.19\end{aligned}$ & $\begin{array}{l}1.4 \\
\pm 0.26\end{array}$ & $\begin{array}{c}14.3 \\
\pm 0.53\end{array}$ & $\begin{aligned} & 3.3 \\
\pm & 0.38\end{aligned}$ & $\begin{array}{r}16.3 \\
\pm 0.49\end{array}$ \\
\hline \multicolumn{11}{|c|}{ Cholesteryl esters } \\
\hline Control & 5 & $\begin{array}{c}21.0 \\
\pm 1.66\end{array}$ & $\begin{aligned} & 8.1 \\
\pm & 0.72\end{aligned}$ & $\begin{array}{c}17.6 \\
\pm 1.66\end{array}$ & $\begin{array}{c}17.5 \\
+1.48\end{array}$ & $\begin{array}{c}16.0 \\
\pm 1.66\end{array}$ & $\begin{array}{l}3.8 \\
+0.40\end{array}$ & $\begin{array}{c}7.7 \\
+0.49\end{array}$ & $\begin{array}{ll} & 3.5 \\
\pm & 0.54\end{array}$ & $\begin{array}{r}11.5 \\
\pm 1.34\end{array}$ \\
\hline PMSF & 7 & $\begin{array}{c}17.2 \\
\pm 1.21\end{array}$ & $\begin{aligned} & 6.5 \\
\pm & 0.26\end{aligned}$ & $\begin{array}{c}17.7 \\
\pm 1.67\end{array}$ & $\begin{array}{c}10 \cdot 1 \\
\pm 0.98\end{array}$ & $\begin{array}{c}11.7 \\
+0.79\end{array}$ & $\begin{aligned} & 3.9 \\
+ & 0.42\end{aligned}$ & $\begin{array}{l}9.1 \\
+0.72\end{array}$ & $\begin{aligned} & 4.5 \\
+ & 0.34\end{aligned}$ & $\begin{array}{r}20.3 \\
\pm 1.36\end{array}$ \\
\hline \multicolumn{11}{|c|}{ Triglyceride } \\
\hline Control & 5 & $\begin{array}{c}33 \cdot 6 \\
\pm 2 \cdot 01\end{array}$ & $\begin{array}{c}1.1 \\
\pm 0.18\end{array}$ & $\begin{array}{c}3.6 \\
\pm 0.81\end{array}$ & $\begin{array}{c}13.2 \\
\pm 0.81\end{array}$ & $\begin{array}{c}3.3 \\
+0.09\end{array}$ & $\begin{array}{l}1.0 \\
+0.18\end{array}$ & $\begin{aligned} & 6.0 \\
+ & 0.45\end{aligned}$ & $\begin{array}{c}6.4 \\
\pm 0.94\end{array}$ & $\begin{array}{r}32.0 \\
\pm 2.59\end{array}$ \\
\hline PMSF & 7 & $\begin{array}{c}37.7 \\
\pm 2.00\end{array}$ & $\begin{array}{c}0.9 \\
\pm 0.08\end{array}$ & $\begin{array}{l}8.9 \\
\pm 0.91\end{array}$ & $\begin{array}{c}12.6 \\
\pm 0.87\end{array}$ & $\begin{aligned} & 2.7 \\
\pm & 0.26\end{aligned}$ & $\begin{array}{l}0.7 \\
\pm 0.19\end{array}$ & $\begin{array}{c}3.1 \\
\pm 0.26\end{array}$ & $\begin{aligned} & 3.6 \\
\pm & 0.45\end{aligned}$ & $\begin{array}{r}27.4 \\
\pm 1.59\end{array}$ \\
\hline \multicolumn{11}{|c|}{ Phospholipid } \\
\hline Control & 5 & 38.5 & $1 \cdot 2$ & $8 \cdot 3$ & $11 \cdot 9$ & $4 \cdot 8$ & 0.9 & $16 \cdot 0$ & $1 \cdot 9$ & $16 \cdot 5$ \\
\hline PMSF & 7 & $\begin{array}{c} \pm 1.40 \\
39.1 \\
\pm 1.4\end{array}$ & $\begin{array}{ll} \pm & 0.13 \\
+ & 0.15\end{array}$ & $\begin{array}{l}9.9 \\
9.9 \\
\pm 0.34\end{array}$ & $\begin{array}{c} \pm 0.23 \\
12.7 \\
\pm 0.38\end{array}$ & $\begin{array}{l} \pm 0.10 \\
5.3 \\
\pm 0.15\end{array}$ & $\begin{array}{l} \pm .09 \\
1.2 \\
\pm 0.23\end{array}$ & $\begin{array}{c} \pm 0.50 \\
15.9 \\
\pm 0.64\end{array}$ & $\begin{array}{l} \pm 0.13 \\
2.0 \\
\pm 0.15\end{array}$ & $\begin{array}{r} \pm 0.81 \\
12.7 \\
\pm 0.57\end{array}$ \\
\hline
\end{tabular}

Values are mean \pm s.e.m.

\section{Discussion}

It was considered unlikely that the PMSF was having a general toxic effect because body and testicular weights were unaffected. The significant decrease in the cholesterol esterifying and cholesteryl ester hydrolysing activities after administration of PMSF and the greater effect on the hydrolytic activity would result in the relative accumulation of cholesteryl esters in the testes of rats during administration of PMSF, as demonstrated in the testes of mice by Bartke et al. (1973). The significant increase in the concentration of free cholesterol (Table 1) might be due to 
the suppression of the activity of cholesterol esterification. However, there was no effect on the activity of cholesterol side-chain cleavage enzyme in the testes of animals treated with PMSF and, as expected, PMSF appears to inhibit selectively cholesterol esterase activity. The decreased concentration of serum testosterone after administration of PMSF confirms for rats the observations of Barkte et al. (1973) for mice. The PMSF also caused the significant decrease in $\mathrm{LH}$ release, indicating that PMSF also acts on the pituitary-hypothalamic system. Such a decrease, together with a change in prolactin levels, could affect the mobilization of cholesterol that is available for conversion into androgens, as shown in mice (Bartke, 1971b).

The accumulation of docosapentaenoic acid in the testicular cholesteryl esters of rats treated with PMSF suggests that cholesterol esterase exhibits a selectivity for the hydrolysis of unsaturated fatty acids. The observation of a direct correlation between the mobilization of cholesteryl esters and androgen production, and the fact that the reaction is under hormonal regulation (Moyle \& Armstrong, 1970; Bartke, 1971a,b; Hafiez, Bartke \& Lloyd, 1972b) suggests that cholesteryl docosapentaenoate is related to steroidogenesis. Accordingly, cholesterol esterase activity might be a regulatory site of androgen production in testes as has been suggested for this enzyme system in ovarian tissues (Behrman \& Armstrong, 1969; Behrman \& Greep, 1972). Behrman \& Armstrong (1969) have suggested that cholesterol esterification might facilitate the transport of cholesterol to the site of synthesis. Cholesteryl docosapentaenoate in testes may have particular physico-chemical properties which facilitate transport and utilization of cholesterol at the site of steroidogenesis.

\section{References}

Alid, G. \& Orrego, F.J. (1972) Inhibition of mammalian acetylcholinesterase by phenylmethanesulfonylfluoride. Experientia 28, 13-14.

Allain, C.C., Poon, L.S., Chan, C.S.G., Richmond, W. \& Fu, P.C. (1974) Enzymatic determination of total serum cholesterol. Clin. Chem. 20, 470-475.

Bartke, A. (1971a) Concentration of free and esterified cholesterol in the testes of immature and adult mice. J. Reprod. Fert. 25, 153-156.

Bartke, A. (1971b) Effects of prolactin and luteinizing hormone on the cholesterol stores in the mouse testis. J. Endocr. 49, 317-324.

Bartke, A., Musto, N., Caldwell, B.V. \& Behrman, H.R. (1973) Effects of a cholesterol esterase inhibitor and of prostaglandin $\mathrm{F}_{2 \alpha}$ on testis cholesterol and on plasma testosterone in mice. Prostaglandins 3, 97 103.

Behrman, H.R. \& Armstrong, D.T. (1969) Cholesterol esterase stimulation by luteinizing hormone in luteinizing rat ovaries. Endocrinology 85, 474-480.

Behrman, H.R. \& Greep, R.O. (1972) Hormonal dependence of cholesterol ester hydrolase in the corpus luteum and adrenal. Horm. Metab. Res. 4, 206-209.

Daane, T.A. \& Parlow, A.F. (1971) Periovulatory patterns of rat serum follicle stimulating hormone and luteinizing hormone during the normal estrous cycle: effects of pentobarbital. Endocrinology 88, 653-663.

Davis, J.T., Bridges, R.B. \& Coniglio, J.G. (1966) Changes in lipid composition of the maturing rat testis. Biochem. J. 98, 342-346.
Goswami, A. \& Williams, W.L. (1967) Effect of hypophysectomy and replacement therapy on fatty acid metabolism in the rat testis. Biochem. J. 105, 537543.

Hafiez, A.A. \& Bartke, A. (1972) Effect of hypophysectomy on cholesterol metabolism in the testes of rats and mice. J. Endocr. 52, 321-326.

Hafiez, A.A., Lloyd, C.W. \& Bartke, A. (1972a) The role of prolactin in the regulation of testis function: the effects of prolactin and luteinizing hormone on the plasma levels of testosterone and androstenedione in hypophysectomized rats. J. Endocr. 52, 327-332.

Hafiez, A.A., Bartke, A. \& Lloyd, C.W. (1972b) The role of prolactin in the regulation of testis function: the synergistic effects of prolactin and luteinizing hormone on the incroporation of $\left[1-{ }^{14} \mathrm{C}\right]$ acetate into testosterone and cholesterol by testes from hypophysectomized rats in vitro. J. Endocr, 53, 223-230.

Hillier, S.G., Brownsey, B.G. \& Cameron, E.H.D. (1973) Some observations on the determination of testosterone in human plasma by radioimmunoassay using antisera raised against testosterone-3-BSA and testosterone-11 $\alpha$-BSA. Steroids 21, 735-745.

Kitz, R. \& Wilson, I.B. (1962) Esters of methanesulfonic acid as irreversible inhibitors of acetylcholinesterase. J. biol. Chem. 237, 3245-3249.

Lowry, O.H., Rosebrough, N.J., Farr, A.L. \& Randall, R.J. (1951) Protein measurement with the Folin phenol reagent. J. biol. Chem. 193, 265-275.

Menon, K.M.J., Dorfman, R.I. \& Forchielli, E. (1967) Influence of gonadotropins of the cholesterol-sidechain cleavage reaction by rat-testis mitochondrial preparations. Biochim. biophys. Acta 148, 486-494. 
Moyle, W.R. \& Armstrong, D.T. (1970) Stimulation of testosterone biosynthesis by luteinizing hormone in transplantable mouse leydig cell tumors. Steroids 15, 681-693.

Pavlic, M. (1970) The inhibition of butyrylcholinesterase by methanesulfonyl fluoride. Biochim. biophys. Acta 198, 389-391.

Stoffel, W., Chu, F. \& Ahrens, E.H., Jr (1959) Analysis of long-chain fatty acids by gas-liquid chromatography. Analyt. Chem. 31, 307-308.
Takatori, T., Phillips, F. \& Privett, O.S. (1976) Effects of dietary saturated and trans fatty acids on cholesteryl ester synthesis and hydrolysis in the testes of rats. Lipids 11, 357-363.

Takatori, T. \& Yamaoka, A. (1977) The mechanism of adipocere formation. 1. Identification and chemical properties of hydroxy fatty acids in adipocere. Forensic Sci. 9, 63-73.

Received 18 April 1978 